\title{
TRIESTE AND LOUIS ADAMIC'S TRANSNATIONAL IDENTITIES
}

John Paul ENYEART

COBISS 1.01

\section{ABSTRACT}

\section{Trieste and Louis Adamic's Transnational Identities}

By examining Slovene immigrant to the United States and world-renowned author Louis Adamic's effort to mediate between his Yugoslav and American identities, this article helps us to think what having a transnational identity means. By focusing on Adamic's writings about Trieste and Italy in general, the article shows how he transitioned from being a disaporic leader during World War II to an anti-colonialist from 1946-1951. Examining Adamic's activist stances regarding Trieste helps us to think about transnationalism beyond a single cross-border movement or an individual's identity claim at a specific moment. Adamic's effort to convince the U.S. government that Yugoslavia should control Trieste allows us to see how transnationalism operated as an identity in flux.

KEY WORDS: Adamic, diaspora, anti-Colonialism, Tito, transnational activism

\section{IZVLEČEK}

\section{Trst in transnacionalne identitete Louisa Adamiča}

Članek s pomočjo prizadevanj slovenskega priseljenca v Združene države in svetovno znanega pisatelja Louisa Adamiča, da bi krmaril med svojima dvema identitetama, jugoslovansko in ameriško, kaže, kaj v praksi pomeni transnacionalna identiteta. $\mathrm{Na}$ podlagi Adamičevih splošnih zapisov o Trstu in Italiji osvetljuje njegov prehod od vodje diaspore med drugo svetovno vojno do antikolonialista v letih 1946-1951. Analiza Adamičeve aktivistične drže do Trsta omogoča lažje razumevanje transnacionalizma onkraj posameznikovega čezmejnega premika oziroma posameznikove trenutne identitetne opredelitve. Adamičeva prizadevanja, da bi vlado ZDA prepričal o nujnosti jugoslovanskega nadzora Trsta, omogočajo vpogled $v$ delovanje transnacionalizma kot identitete $v$ gibanju.

KLJUČNE BESEDE: Adamič, diaspora, antikolonializem, Tito, transnacionalni aktivizem

PhD in History, Professor of History, Bucknell University, 067 Coleman Hall, Department of History, Bucknell University, Lewisburg, Pennsylvania, 17837; jenyeart@bucknell.edu — The author deals with Adamic's leadership in the South Slavic diaspora and his anti-colonialism in his book Death to Fascism (Enyeart 2019). By focusing on Trieste, this article builds on his previous work and emphasizes his relationship to transnationalism more directly. 


\section{INTRODUCTION}

On June 4, 1946, the famous author and social justice activist Louis Adamic wrote a public letter to United States Secretary of State James Byrnes urging him to support Yugoslavia's claim to Trieste. The secretary, who represented the United States in post-World War II peace talks with the other Allied nations, favored giving the port city to Italy over Yugoslavia. During World War II, Adamic and his fellow leftist South Slavic activists helped to convince the American people and the United States government to champion the cause of Communist guerrilla fighter Josip Broz Tito. Tito and his Partisan army battled both the Axis forces who invaded Yugoslavia in 1941 and the Serbian Chetniks that wanted to reinstall the monarchy that had ruled that country from the end of World War I through the fascist takeover. By 1946, federal officials such as Byrnes wanted to end their alliances with Communists as they started to insist that communism had replaced fascism as the greatest danger to democracy globally. Therefore, Byrnes and others in Harry S. Truman's Administration decided to advocate on behalf of a recent enemy, Italy, over an ally, Yugoslavia. Adamic insisted that Byrnes was using the rhetoric of anticommunism to make the Democratic Party's desire for expanding its political power and assisting American business's interests more palatable to the American people.

Byrnes cited ethnic ties as his primary reason for wanting to award Trieste to Italy, as he claimed that more of the city's population identified as Italian as opposed to Slovenian. Adamic rejected this claim. He asserted that turning Trieste over to the Italians "would reward criminality and punish its victims" because, as the State Department's reports clearly documented, the Italians had attempted to "eradicate the Slovenians and Croatians in the area" even before Benito Mussolini took power (Adamic 1946: 2). Adamic contended that most people living in and near Trieste, including most Italians, sympathized with Tito's Partisans and their promotion of ethnic diversity. Adamic then proclaimed that the United States had "been led into this complicated game by the British, by the Vatican, by the [Truman] Administration's concern for the 'Italian' [American ethnic] vote in 1946 and '48, [and] by our desire to stop the spread of Soviet influence" (ibid.: 2, 6). Adamic meant that Britain and the U.S. believed they would reap greater benefits from trade that went through an Italian Trieste than they would from a Yugoslavia that western leaders assumed would be under Stalin's influence. Adamic added that Byrnes's position made the U.S. look like it was taking a stand against Communism as anticommunist sentiment was on the rise in the United States. Last, Catholics, and ethnic Italians in particular, had become a key constituency for the Democratic Party. Adamic accused Byrnes and Truman of pandering to Italian Americans in preparation for the 1946 mid-term elections and the 1948 presidential election.

Examining Adamic's effort to convince United States government officials and the American public that Trieste should be part of Yugoslavia allows us to sharp- 
en our understanding of how transnational identities ebbed, flowed, and changed. Adamic adopted, shed, and reformulated his identity based upon the tenuous alliance and then growing tensions between his host land and homeland. Early in his career, he wrote as an exile, and then he argued that like other "new" Americans he was hybrid of Slovenia and the United States (Žitnik 1998: 95-110; Shiffman 2003: 142-165; Enyeart 2019: introduction). This article will focus on his sense of being later in his life, when he saw himself as a diasporic leader during World War II and then when he proclaimed himself an anti-imperialist from 1946 through his death in 1951. Each of his states of being represented expressions of living a life guided by a transnational awareness.

Defining transnationalism has become difficult for scholars, as different disciplines use the term in various ways. Some academics see it as sets of financial, cultural, and political networks between sending and receiving communities. Others focus on the mobilization of migrants around their diasporic experience; and still others see it as the fashioning of hybrid identities based on intra and interethnic relationships. Broadly, historians, sociologists, anthropologists, and geographers agree that those who forged transnational identities acquired a sense of themselves across multiple borders by engaging with global events in their local communities (Basch, Schiller, Bland 1994: 27; Jacobson 1995: 13-53; Guglielmo 2010: 3-4; Portes 1997: 813; Foner 2000: 169-187; Seigel 2005: 62-90). Some of the best transnational studies concentrate on how migrant laborers in the United States confronted their employers by incorporating boycotts from Ireland, peasant women's revolutionary practices from Italy, and anarchism forged on the Mexican-U.S. border (Guglielmo 2010: 3-4; Brundage 2016: 8-33; Weber 2016: 188-226). These works have pushed us beyond exceptionalist thinking by explaining how a specific phenomenon resulted from cross-border interactions.

Examining Adamic's activist stances regarding Trieste helps us to think beyond a single cross-border movement or an individual's identity claim at a specific moment, and thus allows us to see how transnationalism operated as an identity in flux. Adamic's shift from diasporic leader to anti-colonial activist allows us to use one person to gain insights on how transnational movements changed in reaction to evolving local and global dynamics.

The fight over Trieste helped to precipitate Adamic's shift from a leader of the leftist South Slavic diaspora to a proponent of anti-colonialism. 'The different versions he told of the Trieste fight reflected those changes and are examined in this article. Yugoslavia's claim to Trieste, he argued, represented the South Slavs' efforts to have a homeland and fulfill their long-held desire for self-determination. By the summer of 1946, it had become clear to him and to most observers that the U.S. would support Italy's claim on Trieste. At that point, Adamic pointed to Trieste as an example of America's expanding imperialist desires.

1 For more on American responses to Slovenian claims on Yugoslavia see Novak 1977: 1-25. 
In order to understand how Adamic defined and redefined his politics during and after World War II, this essay begins by explaining how Adamic embraced the South Slavic diaspora, and became its leader. Then it turns to the controversy over Trieste and Adamic's effort to convince the United States government to award the port city to Yugoslavia. After Yugoslavs shot down what they believed were American spy planes, Adamic knew that corporate leaders and their political allies would use the growing anticommunist sentiment in the United States to support Italy's claim on Trieste. Adamic then decided to abandon his advocacy for U.S. support of the New Yugoslavia under Tito's leadership and instead insisted that the Trieste case exemplified how imperialism worked in the post-World War II world under American hegemony.

\section{ADAMIC AND THE SOUTH SLAV DIASPORA}

At fourteen years old, Alojzij Adamič left Slovenia in the fall of 1912 and arrived in New York City that December. ${ }^{2}$ He performed various jobs ranging from errand boy in a newsroom to dockworker, until he enlisted in the United States Army during World War I. Using a typewriter without diacritical marks, the army clerk who filled out Adamic's induction papers changed Adamič to Adamic. Louis kept it. By the late 1920s, editors of the nation's leading magazines were publishing Adamic's articles that criticized the oppression American workers experienced and the xenophobia immigrants faced. By the early 1930s, he had started concerning himself with the politics of his homeland, which was now part of the Kingdom of Yugoslavia. In 1934, Adamic proclaimed that Alexander - the Serbian irredentist king who had turned the recently created nation of South Slavs into a police state - shared a worldview with Adolph Hitler, Benito Mussolini, and the Ku Klux Klan (Adamic 1934a: 35; Adamic 1935: 3-5; Lees 2007: 55). By 1942, Adamic argued that Tito, who sought simultaneously to liberate Yugoslavia from its fascist enemies and the Chetniks battling to restore the Serbian monarchy, epitomized the antifascist spirit guiding the Allied war effort.

Supporting Tito was Adamic's most recent iteration in the abiding process of synthesizing his Slovenian and American identities. When he first arrived in the United States, Adamic stood aloof from Slovene and American politics. He, however, did remain connected to his Slavic roots by translating his favorite authors from Slovenian into English. Then he criticized Alexander's government in his The Native's Return (1934) and translated Slovenian Communist Edvard Kardelj's pamphlet Struggle (1934), that detailed Alexander's surveillance and torture methods. In the early 1930s, Adamic championed cultural pluralism, the idea that democracy depended on ethnic and racial equality. In the early 1940s, inspired by Tito, he revised his understanding

2 Scholars have been confused about when Adamic left Slovenia because Adamic wrote down the wrong date. The manifest from the ship Adamic traveled on to reach the U.S. showed that he departed Europe in the fall of 1912 and arrived at Ellis Island in December. 
of cultural pluralism. Tito mobilized his Partisans by promising that the new Yugoslavia would replace Serbian ethno-nationalist rule with equality for all South Slavs. Adamic asserted that Tito had revolutionized pluralism and repeatedly made his point by contrasting Tito's pan-Slavic vision with the justifications for immigration restriction and Jim Crow in the United States and imperialism in Britain. In supporting Tito, Adamic had embraced the South Slavic narrative of diaspora (Enyeart 2019: chapters 3, 4).

Tito's vision of an ethnically equal nation was one iteration of Yugoslavism, a vision of South Slavic diaspora. During the 1830s, Croatian intellectuals first articulated the idea of a united land of South Slavs. They feared losing both their territory and language under Habsburg rule and began arguing that Serbs, Croats, and Slovenes belonged to one ethnic group. By 1914, exiled South Slav politicians in London published pamphlets declaring that foreign rulers had prevented this ethnic group from creating its own state. The collapse of the Habsburg Empire at the end of World War I created the opportunity for Yugoslavia to become a reality. They created the Kingdom of Serbs, Croats and Slovenes at the end of 1918, which in 1929 was renamed the Kingdom of Yugoslavia. The change in name accompanied King Alexander's enactment of a dictatorial monarchy (Djokic 2003: 18-19; Ramet 2009: 141-142). Fissures manifested immediately. In 1918, terrorist bands, extreme nationalist groups, and radical organizations, including the Communist Party, operated illegally in interwar Yugoslavia. By 1939, complaints about an unfair tax structures, a Serbianized education system and political repression led to a divided nation rife with ethnic, religious, and political hatreds (Ramet 2009: 141-142). Slovene and Croatian Catholics and Serb, Slovene, and Croatian Communists, for example, could agree that Alexander did not represent their vision of Yugoslavism, but neither could those groups find unity (Rogel 1977: v-vii, 14-27, 75-89; Banac 1992: 1084-1104).

In the United States, leftist South Slavic immigrants, led by Slovenian socialists, forged their vision of Yugoslavism before Yugoslavia ever existed. From the 1880s through 1914, South Slavic immigrants arrived in Cleveland, Chicago, and smaller industrial centers in the U.S. In the early twentieth century, those with left-wing political leanings created the Yugoslav Socialist Federation (YSF), affiliated with the Socialist Party of America. In 1917, YSF members passed the "Chicago Declaration" that resolved to raise funds for and lobby on behalf of a federated Yugoslav republic (Klemenčič 1999: 43).

Exiles such as the Ljubljana-born journalist and labor activist Etbin Kristan highlighted the YSF's role in coordinating transnational political activism. In 1896, Kristan, helped to form the Yugoslav Social Democratic Party. By 1912, he had established firm connections between his party and YSF activists in Chicago. When World War I began, he immigrated to the U.S. (Jurak 1985: 53-54).

The YSF splintered during World War I. Some members supported the war because they saw it as a catalyst to Yugoslavism. Others joined those in the larger Socialist Party who criticized the conflict as a mass slaughter of the working class for 
capitalist gain. Further divisions arose within the YSF when some members inspired by the Russian Revolution embraced Communism.

During the interwar period, South Slavic newspapers in the U.S. still promoted Yugoslavism, but political divisions between Socialists, Communists and Catholics prevented any meaningful challenges to Alexander's autocracy by American South Slavs. Some Socialist and Communist newspaper editors did agree that Adamic did not represent the South Slavic community. In 1938, the editors of the leading leftist Slovenian language newspapers in the U.S. criticized Adamic for spending most of his time outside of South Slav ethnic communities. They pointed out that he did not live in South Slav neighborhoods, had married a Jewish American woman, did not often write for Slovenian American newspapers, and had not joined Slovenian or South Slav ethnic associations. ${ }^{3}$

Despite these criticisms, Adamic remained popular among large segments of his fellow ethnic Slovenes and South Slavic Americans in general. For example, after he had exposed Alexander's oppressive rule to the English-speaking world in Struggle and The Native's Return, conservative Slovenian and Serbian American supporters of Alexander denounced him. Cleveland resident Anne Grill responded by organizing the Daughters of Slovenia, which soon became the Progressive Slovene Women of America (PSWA). The PSWA promoted Adamic's work and helped to revive a leftist vision of Yugoslavism over the next four years as activists established branches in Milwaukee, Chicago, St. Louis, and numerous industrial centers (Klemenčič 1995: 210-211).

Another example of Adamic's popularity within the Yugoslav-American community came in the summer of 1943 when he helped to create and then agreed to lead the United Committee of South Slavic Americans (UCSSA). The UCSSA lobbied the American government to assist Tito's Partisans and criticized nativism and racism in the United States (Bulletin of the United Committee of South-Slavic Americans hereafter BUCSSA 1943: 1-2). In a letter to Franklin Roosevelt outlining these aims, Adamic also urged the President to support Yugoslavia's claim to Trieste. ${ }^{4}$

Adamic agreed to lead the UCSSA because his worldview had shifted from seeing himself as an exile promoting cultural pluralism in the United States to a champion of global democracy fighting fascism. Germany's invasion of Poland in 1939 spurred Adamic's shift in thinking about democracy globally as he started to see fascism as the greatest danger the world faced. In a letter to the president of the Yugoslav Catholic Union that year, he proposed that they work together to create an organization that united American Slovenes, Croats, and Serbs concerned with the affairs of their former homeland. That effort stalled as leftists and Catholics could not reconcile their political differences (Klemenčič 1995: 364-365). After failing in

3 Molek, Ivan to Louis Adamic (1938). May 11. Chicago History Museum, Ivan Molek Papers, Box 1, file folder 3 .

4 Adamic, Louis to Franklin Roosevelt (1943). July 26. Narodna in univerzitetna knjižnica, Ljubljana, Louis Adamič Papers, pisma 3, mapa 9. 
an effort to unite Slovenians in the U.S. in the Slovene American National Council (Slovensko-ameriški narodni svet or SANS), Adamic finally succeeded his quest to form a pan-South Slavic group to advance Yugoslavism when he helped to create the UCSSA. SANS split along ideological lines as Catholic anticommunist Slovenes protested the organization's pro-Tito stance.

Adamic's writing reflected his diasporic activism. He revised how he thought of his relationship to his homeland and host land by envisioning himself as part of the Slovenian and South Slav migration. A subset of South Slavs argued that the repression they experienced under the Austrian monarchy had forced them out their homeland and they could not return to the recently formed Yugoslavia because Serbian kings continued to oppress Croats and Slovenes politically and culturally. By 1941, the fascists threatened to extinguish any hopes for Yugoslavism. In his My Native Land (1943), which appeared the same year he and other activists established the UCSSA, Adamic explained that "Yugoslavia was never properly born. It had been conceived through an inevitable convergence of historical forces, but the midwives attending the birth had bungled their job." Because Serbian autocrats undermined the desire for equality at the heart of Yugoslavism, many South Slavs

simply knew in their bones that the Balkan peoples must extricate themselves from the simultaneously heavy and subtle apparatus of Western imperialism. There was but one way to do that - to go the way of Russia; to work out a procedure whereby "backward" nations and their undeveloped resources would be withdrawn from the reach, from the sphere, of intrigue and "prestige" of the predatory and in the long run incompetent Great Powers of the West. (Adamic 1943: 393)

Significantly, Adamic cited "Western imperialism" as a key factor in preventing the realization of Yugoslavism. But he did not yet argue that liberation for South Slavs would have to come through unity with other colonized peoples. He made the South Slavs who joined the Communist underground the protagonists in My Native Land and he praised them for advancing Yugoslavism. Being a diasporic leader defined his transnational activism during World War II.

In championing Yugoslavism, Adamic adjusted his framing of peasants. No longer doomed to lives of perpetual despair, Adamic now presented South Slavic peasants, a group within which he included himself, as a dispersed people patiently waiting to create their own future. He cited Slovene literary critic and Communist underground activist Josip Vidmar's argument that South Slavic peasants, along with some intellectuals, whether "they were in Yugoslavia, in Italy or Austria or Hungary, or immigrants in South or North America" possessed slovenstvo, i.e. Sloveneness, or the Slovene spirit. Slovenstvo linked Slovenes culturally and spiritually wherever they lived and it would guide them to join the fight to make Slovenia an equal partner in a new Yugoslavia at the right moment (ibid.: 136, 138-139). 
Tito's Liberation Front embodied the diaspora's vision for a land of South Slavic equals through its "new heroism," as the Partisans hurled themselves "against the errors of the past wherever they continued to function, breaking its fetters and releasing the energy belonging to the future" (ibid.: 396). Adamic now portrayed the diaspora that he once rejected as an alliance of the Communist underground and their antifascist allies in Yugoslavia and exiled South Slav peasants turned American workers. Tito's revolutionaries, according to Adamic, now made the Yugoslavia long dreamed of through war, while Adamic and his fellow South Slavs living abroad lobbied allied governments to support the Partisans militarily, monetarily, and politically. They succeeded.

Success meant that by the summer of 1943, Adamic and his supporters had convinced much of the American public that a number of Chetniks had collaborated with the fascists in fighting the Partisans, and that Chetnik General Draza Mihailović had agreed not to engage Axis forces. Around the same time, the U.S. and British governments changed their support from Mihailović to Tito. Many journalists credited Adamic with influencing this decision, but British intelligence reports documenting Chetnik deals with Axis forces had a much greater influence on the Allied nations' shift in thought (Enyeart 2019: Chapter 3).

\section{DEMANDING A YUGOSLAV TRIESTE}

After World War II, the UCSSA updated its objectives. The group supported the Allied nations' "efforts toward world peace," encouraged American South Slavs to "participate fully in all processes to advance political, economic, social and ethnic democracy in the United States of America," and to "foster in the United States of America an ever greater understanding of the South-Slavic peoples, their history, culture and traditions" (BUCSSA April 1946: 3). Italy figured prominently in Adamic's lobbying efforts. For example, Adamic and Kristan, along with other officials of SANS, which became part of the UCSSA, attempted to free Slovenian Prisoners of War (POWs) held by the U.S. government. Italian military officers forced Slovenians in Italian controlled places to fight in the Italian army during World War II. Kristan explained to Under-secretary of State Sumner Welles that "these men cannot really be considered enemies of the United States; for they have been forced to join the Italian army, and we definitely know that their sympathy was never with Italy, much less with fascism." They were especially talking about ethnic Slovenes living near Trieste. ${ }^{5}$

When that group, which included Adamic, met with Welles, they brought letters from antifascist Slovenians from the Littoral. One letter they presented to Welles from a Slovenian stated: "We have the national feeling which has been stifled and

5 Kristan, Etbin to Sumner Welles (1943). July 15. Narodna in univerzitetna knjižnica, Ljubljana, Louis Adamič Papers, Tuja korespondenca 4, mapa 21. 
tramped upon since our birth, but secretly instilled and cultivated by our mothers during our childhood. 'This love was also with us during the unbearable hours under the foreign yoke, when we were forced to go to the war front." The writer continued that Italian fascists "destroyed our homes and thrown our parents into the street. Many were shot. Many of us have sisters in concentration camps - and brothers fighting the enemy together." ${ }^{16}$

Using letters such as this one, Adamic implored Welles to urge his superiors to support Tito and the Partisans. He drew examples from similar correspondence on his speaking tours to convince the American public to support Tito and the leftist South Slav vision of Yugoslavism (Enyeart 2019: Chapter 3).

U.S.-Italian-Yugoslav relations were the UCSSA's top concern. In June 1944, Zlatko Baloković, a world-renowned concert violinist who emigrated from Croatia to the United States, took over the day-to-day leadership of the UCSSA from Adamic when doctors ordered Adamic to rest because of exhaustion. Baloković's new responsibilities included editing The Bulletin of the United Committee of South-Slavic Americans, the UCSSA's newsletter, and with help from Adamic, Baloković kept the focus largely on events in post-war Italy. In an October 1945 article, for instance, The Bulletin reported that "war criminals" now held government positions in Italy's provisional government. Baloković also republished articles from other periodicals dealing with Yugoslav-Italian issues, such as Blair Bolles' piece from the August 1945 journal PM. Bolles pointed out that the U.S. government applied sanctions against Tito's government, which diverted 5000 tons of sugar from Yugoslavia to Greece. More importantly, these sanctions led to the Yugoslav government's inability to secure bank loans that would allow them to purchase imports. Stressing the Yugoslav-American alliance during World War II, Bolles pointed out the absurdity of this policy. The U.S. placed no sanctions on Argentina's tyrannical government. When reporters asked U.S. government officials about this apparent contradiction, they claimed that these "sanctions would constitute a violation of sovereignty and that to deny U.S. goods to the Argentine people would turn the people away from us" (BUCSSA October 1945: 3). Obviously, the same logic applied to Yugoslavs. When pressed further to address this clear double standard, state department officials responded that Yugoslavia's commitment to the four freedoms remained "unproven". In a 1941 address, President Franklin D. Roosevelt outlined "four essential human freedoms" throughout the world: freedom of speech and of worship, and freedom from want and from fear (Roosevelt 1941; Borgwardt 2005: 4-6, 50, 135-136). Americans claimed that the four freedoms characterized their vision of democracy for the world. Bolles challenged this answer by pointing to Juan Perón's Argentina, Francisco Franco's Spain, and Chang Kai-Shek's China as instances where "reactionary tyrants" received U.S. aid (BUCSSA October 1945: 3).

6 Kristan, Etbin to Sumner Welles (1943). July 15. Narodna in univerzitetna knjižnica, Ljubljana, Louis Adamič Papers, Tuja korespondenca 4, mapa 21. 
Part of Adamic's work with the UCSSA included lobbying politicians to provide monetary aid to Yugoslavia. Despite his health issues, Adamic ignored his doctor's orders when it came to doing this work. On December 6, 1945, Adamic's friend Nick Bez - a Croatian immigrant, Seattle businessman, influential Democratic Party donor, and one of the UCSSA's leading contributors - arranged a meeting between Adamic and President Truman. Adamic kept stressing to Truman that with aid from the United States, Yugoslavia could become a democratic nation. Truman seemed skeptical, but Adamic kept stressing that he had letters from American executives willing to do business in Yugoslavia. He urged Truman to have the State Department look into extending Yugoslavia credit. In a letter to Bez after the meeting, Adamic stated that he brought up Trieste but the "President seemed to bristle at the mention of Trieste, but he said nothing". Adamic explained that Yugoslavs had repaired over 450 miles of railways, including bridges, linking Trieste to Belgrade. He wrote Bez that Truman appeared uninformed and had little understanding of Yugoslavia. ${ }^{7}$

By the spring of 1946, Adamic focused primarily on Trieste and allied with other South Slavic activists to convince the Truman Administration to support Yugoslavia's claim to the port city. In April, he updated arguments about ethnicity, the economy, and politics in the Bulletin. He highlighted the fact that a group called the Italo-Slovene Liberation Committee had been formed in Trieste during World War II in opposition to the Italian government and the Axis powers as they fought with the Partisans. That group argued that Trieste should be part of Yugoslavia. Despite examples such as this one, Adamic feared that Trieste's fate would be decided by American business interests and the Democratic Party's desire to shore up its base. The Truman Administration, Adamic asserted, would continue to frame these objectives as efforts to advance democracy as tensions between the U.S. and the USSR grew (BUCSSA April 1946: 1).

In May, a group calling themselves the Seattle Tacoma and State of Washington Jugoslavs sent the President a telegram declaring that Trieste "without the Slavic hinterland is a dead city". The cable declared that Yugoslavs "living in the disputed area were brutally maltreated for twenty-five years and were forced by the Italian government to lose their national identity" and "were forced into exile". As a result, they lost their land and thus became victims of "empire and conquest". ${ }^{8}$ They were refuting Byrnes's repeated assertion that most residents of Trieste were Italian and thus Trieste should be awarded to Italy. Marcus Nalley, an influential member of the Seattle-Tacoma and State of Washington Jugoslavs, sent Adamic a copy of the telegram. Nalley, a Croatian immigrant and Tacoma businessman who made and sold potato chips, entered into a correspondence with Adamic. Nalley and Adamic commiserated about how misinformed the larger American public was about Yugoslavia

$7 \quad$ Adamic, Louis to Nick Bez (1945). December 17. Princeton University, Firestone Library, Rare Books and Special Collections Department, Louis Adamic Papers, Box 45, folder 6.

8 Nalley, Marcus to Louis Adamic (1946a). May 8. Princeton University, Firestone Library, Rare Books and Special Collections Department, Louis Adamic Papers, Box 45, folder 6. 
and they strategized about how best to advance the Trieste issue. ${ }^{9}$ Adamic wrote to Nalley that Trieste was now tied to "big-power politics between the Anglo-American combination on the one side and Russia on the other", and Trieste was also connected to "our internal American politics". Adamic encouraged Nalley and his group to keep sending telegrams to Truman and Byrnes. ${ }^{10}$

When Adamic had met with Truman, he explained that businessmen supported the UCSSA's effort to work with Tito's Yugoslavia, and shared his belief that trade between the two countries could move Yugoslavia toward democracy. Bez and Nalley's alliance with Adamic demonstrated that a broad swath of South Slavs, not just Communists, shared this view. Contrary to anticommunist claims, Communism was not a monolithic project controlled by the Soviets. Awarding Trieste to Yugoslavia and engaging in trade with Tito's government would have demonstrated this point. The irony was that after Tito broke from Stalin in 1948, the U.S. government sent money to Yugoslavia, forging a tenuous alliance with Tito. By that point, however, Yugoslavs did not trust either country and steered an independent course between the U.S. and USSR for the rest of its existence (Lees 1997: 10-11).

Father James Cherne, a Catholic priest who had lived in occupied Italy and ended up in a German prison camp, also helped Adamic make his case for awarding Trieste to Yugoslavia. Cherne wrote Byrnes of the Slovene soldiers' bravery during the war and stressed to the secretary that Trieste never belonged to the Kingdom of Italy. Cherne did note that it was briefly part of the Kingdom of Venice, but its residents voluntarily decided to join the Austrian Empire. Thus, just in case Byrnes actually believed Trieste's past linked it to Italy, the UCSSA and its supporters repeatedly attempted to correct that detail for him (BUCSSA May 1946: 21).

Other than Truman and members of his administration, Adamic also worked with members of congress as part of his role as a leader in the South Slavic diaspora. In May 1946, Senator Warren Magnuson, representing the state of Washington, read Adamic's letter to Byrnes into the Congressional Record. Whatever slight chance Adamic and other South Slav activists had to change the outlook of the Truman Administration regarding Trieste ended in the summer of 1946.

\section{U.S. IMPERIALISM AS ANTICOMMUNISM}

By June 1946, newspapers throughout the country started arguing that giving Trieste to Yugoslavia would mean that the U.S, England and France had bent to Russia's will (Democrat and Chronicle, June 4, 1946). In part, the emerging Cold War

9 Nalley, Marcus to Louis Adamic (1946). May 25. Box 48, folder 6, Princeton University, Firestone Library, Rare Books and Special Collections Department, Louis Adamic Papers, Box 48, folder 6 .

10 Nalley, Marcus to Louis Adamic (1946). June 1. Princeton University, Firestone Library, Rare Books and Special Collections Department, Louis Adamic Papers, Box 48, folder 6. 
led the American public to accept anticommunist arguments that presented leftist South Slavs as "Communist stooges" instead of champions of democracy. Increasingly, many South Slavs coming to the United States used this rhetoric to transform themselves from fascists, fascist sympathizers, or supporters of Serbian irredentism into exiles who had tried but failed to save their homeland from the spread of Communism. Their version of who they were competed with the leftist version of Yugoslavism Adamic championed. As a result, tensions grew within South Slavic American communities. Divisions within this ethnic community meant a loss of political influence, as leftist South Slavs could no longer speak in a clear unified voice (Enyeart 2019: chapter 4). This new reality at home and the conflict between the U.S. and Yugoslav governments led Adamic to adopt a new political position.

In August, U.S.-Yugoslav relations severely declined. The Yugoslav military forced one U.S. airplane to land when it crossed over into Yugoslav airspace and then arrested the crew. When a second plane flew into Yugoslav airspace, Tito's solders shot it down, killing the five U.S. airmen on board. The United States government claimed that both planes were on cargo runs and that they veered off course into Yugoslavia. Adamic supported the defense offered by Yugoslav officials that the United States purposefully violated Yugoslav sovereignty by carrying out repeated air reconnaissance missions. Yugoslav officials had repeatedly asked the Truman administration to halt these intelligence-gathering missions. When the espionage campaign continued, the Yugoslavs warned the Americans that they would have no other choice than to fire upon the planes. Byrnes declared his outrage over these attacks and stuck to the official story that these were honest mistakes. The American media fanned the flames of public outrage and reported the government's version of the story (Adamic 1952: 66-72; Lees 1997: 14-15).

Adamic gave speeches and wrote articles that attempted to challenge this version of events, and fight the spread of anticommunism. His most comprehensive effort at correcting the narrative in the United States came in the September 1946 issue of The Bulletin. Yugoslavs, he wrote, wonder why their Allies in the fight against fascism are now "so indulgent toward an enemy, send up Army planes almost daily to reconnoiter a loyal wartime ally and peacetime friend". He also brought up the fact that U.S. government officials withheld Yugoslavs' boats that the Germans had stolen during the war (BUCSSA September 1946: 1). Adamic asked his readers: "what if an unauthorized foreign plane flew over the White House?" (ibid.: 3).

This article marked a clear shift in Adamic's articulation of transnational politics. He recognized that in the atmosphere of mounting anticommunism, Tito's forces shooting down an American plane ended any chance of a continued alliance between the U.S. and Yugoslavia. That development guaranteed that Byrnes and Truman would award Trieste to Italy.

Adamic concluded that attacking American imperialism was the best way to advocate for Yugoslav sovereignty. He was now making a moral appeal based on American-inspired rhetoric first asserted by Woodrow Wilson that advancing democracy 
included an end to imperialism by granting colonized nations the right to self-determination. In the Bulletin, Adamic admonished the New York Times and other newspapers that shaped public opinion for "putting quotation marks around such words as 'American reactionaries' and 'American imperialism' as though they did not exist". To Yugoslavs and others facing the threat of American intervention, "imperialism is not something that went out with Queen Victoria ... Imperialism to them is a very recent arrangement by which western European investors in Yugoslav copper mines drew an annual return of 235 percent of their investments while the Yugoslav workers in these mines - 'natives' - were paid the equivalent of 25 cents a day."

He added that "American reactionaries" promoted policies that "the American press and radio and State Dept." supported, which would transfer wealth from eastern Europe to the US and western Europe (ibid.).

Adamic then explicitly connected U.S. colonialism, the espionage flights, and the Trieste decision. He argued that American military leaders and government officials had incited a provocation with Yugoslavia to "intimidate the Yugoslavs generally on account of their insistence that Trieste rightfully belonged to Yugoslavia" (ibid.: 4). The true un-Americans were not the supporters of peaceful relations with Yugoslavia or other Communist nations, but the "powerful, war-minded forces in this country [who] have deliberately forced a crisis with Yugoslavia in order to crack down on European democracy and force the small nations to take orders from Wall Street" (ibid.: 5). The "banking trusts, the oil corporations and the democracy-haters of America who alone have a stake in fomenting a war situation", he continued, promote colonialism under the cover of anticommunism because the portraying a constant threat of war "means billions of juicy contracts". Adamic concluded: "Only the desire for empire, for cracking down on the independence of other nations, can explain what we are doing" (ibid.: 5-6).

Challenging the spread of American empire remained the central focus of Adamic's work until he died in 1951. His posthumously published The Eagle and the Roots (1952) built on the anti-colonialist arguments Adamic made regarding Trieste. He declared that the "New Yugoslavia's industrialization-through-socialism is primarily anti-imperialism: a holding action - holding on to her natural resources and staving off the greed-and panic-driven jogs and jolts of the big powers" (Adamic 1952: 135). By this point Yugoslavia had broken away from the Soviet Union's influence and attempted to steer an independent path between the U.S. and the USSR. The Soviets and their allies claimed that Tito had betrayed Communism and had become a puppet of the West. U.S. politicians and policymakers, although providing monetary support to Yugoslavia, remained committed to an anticommunist foreign policy. The criticisms of Yugoslavia by both of the "big powers" from Adamic's perspective masked the fact that the U.S. and the USSR wanted to colonize Yugoslavia in their own ways.

Adamic elaborated on his point about U.S. and Soviet imperialism by explaining what was happening in Italy from 1949-1951. He used the Marshall Plan as an 
example of how the neo-colonialism of the United States operated. Implemented by the United States in April 1948, the Marshall Plan tied Western European nations' economies to the U.S. through aid packages, mostly loans, intended for those countries to rebuild and modernize their industries. Communist nations were ineligible for these funds despite the fact that many of them, including Yugoslavia, had played a central role in the Allied victory (La Feber 2008: 57-73). After noting that a number of Italians had emigrated to the New Yugoslavia to "build socialism", Adamic contended that the United States "is more effective in promoting Coca-Cola and Reader's Digest than self-reliance and pride in workmanship". In other words, the United States advanced the interests of its corporations and promoted consumerism instead of the dignity of labor. In the same sentence, Adamic took aim at the Soviets. He pointed out that "the Communist propagandists, extolling the Soviet Union's big-industry system, also belittle individual craft skills of which a man can be proud" similarly disguising the USSR's imperialist desires (Adamic 1952: 241).

He then quoted a conversation he had with Tito on January 18, 1949, to clarify his point. The Yugoslav leader declared that "the billions of dollars which the USA is spending to 'contain Communism' is a waste and confusion: that if Italy and France hadn't received American 'aid', they might have had Communist-led revolutions and, like Yugoslavia, they might now be at odds with the Kremlin if the Russians had tried to butt into their internal affairs and to use them as pawns in the power game against America" (ibid.: 242). Tito added that for the U.S. to maintain its "economic system at its present pitch, America must throw off her financial surpluses someplace, fast. And her improvised statesmanship combines the disposal of those surpluses with a 'contain Communism' policy, which is less anti-Communism than a cover-up for expansionism." Tito proclaimed that Italy "is becoming an American colony. She's a pawn in Washington's power game against Moscow". Italy was crucial to the "route to the Middle East with its vast oil deposits, which Russia would rush in to control and exploit if America didn't" (ibid.: 243). The Cold War, Tito said in his meeting with Adamic, benefitted the expansionist desires of both the U.S. and USSR (ibid.). In The Eagle and the Roots, Adamic no longer presented Yugoslavism as a collective project undertaken by South Slavs determined to build a nation of ethnic equals. Instead, the struggle to make the New Yugoslavia a success exemplified the global struggle of developing nations for self-determination as the U.S. and USSR attempted to expand their post-war visions of empire.

Adamic further displayed his anti-colonialist thinking in a 439-page typescript chapter called "A Game of Chess in an Earthquake" that his editor Timothy Seldes and estranged wife Stella did not included in the final version of The Eagle and the Roots. Adamic argued that politicians, business leaders, and journalists had an embraced authoritarianism and thus advanced this post-war imperial project. Adamic quoted Marine Corps war hero General Smedley D. Butler to highlight his point. Butler was the most decorated U.S. serviceperson in American history by his death in June of 1940. During the 1930s, Butler assessed his life's work and realized that he 
had been "a gangster for capitalism". He said: "I helped make Mexico and especially Tampico safe for American oil interests in 1914. I helped make Haiti and Cuba a decent place for the National City Bank boys to collect revenues. I helped in the raping of half a dozen Central American republics for the benefit of Wall Street."

Butler added that he had aided the sugar industry in the Dominican Republic, and helped export oil from China (Adamic 1951: 244). Adamic then argued that a fascist strain had existed in American politics for a very long time and that politicians and journalists disguised it in the rhetoric of advancing democracy. Butler believed he was advancing democracy until he saw what happened in the places where he commanded troops to put down leftist insurrections. Butler realized that those he defeated were the actual democrats. Adamic argued that the U.S. government was continuing to employ this strategy, but because of American fears of Communism, warnings such as Butler's were being ignored.

Adamic called on Americans to look at the world and support "third-world" uprisings and reject the anticommunist framings of these insurrections as Soviet-inspired efforts to spread Communism. He wanted Americans to see that similar to the Yugoslav revolution, these rebellions were fought by people trying to free themselves from imperialism. For Adamic, Tito's revolution had gone from being the fulfillment of Yugoslavism to a successful example of anticolonial resistance.

Trieste, and Italy in general, played in a central role in how Adamic framed his transnational activism. His initial writings on Trieste, which were part of his effort to lobby the U.S. government to award the port city to Yugoslavia, revealed his dedication as a diasporic leader. As part of the new Yugoslavia, Trieste would have helped to cement the success of Yugoslavism. According to Adamic, it would have helped grow Yugoslavia's economy and put it on a path toward greater democracy. As it became clear that the United States would award Trieste to Italy and not Yugoslavia, Adamic saw American imperialism at work. In his writing and speeches he shifted from being an advocate for Tito to being an opponent of the world the U.S. and the USSR were creating. He used Italy as one example. The U.S. government, he argued, saw Italy as a stepping stone crucial to American businesses' need for more markets. American officials could claim they were helping to rebuild a democratic Italy, but in actuality they simply wanted more consumers.

Adamic's framings of Tito and Italy reflected his changing transnational politics. Balancing his homeland and hostland identities meant that Adamic constantly thought about issues of justice beyond one set of borders. During World War II that meant imploring his homeland to support him and his fellow South Slavs in playing a significant role in making Yugoslavism a reality. But as he saw the Cold War dawn, he rethought how justice could operate globally. He viewed both the anticommunists and the Soviets as masking their expansionist desires with different rhetorics of justice. Justice, he had determined from witnessing the Partisans' struggle, had to come from within a nation, and he urged the global hegemons to support those indigenous uprisings. 


\section{REFERENCES}

Adamic, Louis (1934). The Native's Return: An American Immigrant Visits Yugoslavia and Discovers his Old Country. New York: Harper and Brothers.

Adamic, Louis (1935). Struggle. New York: Tomorrow Publishes (originally published 1934). Adamic, Louis (1943). My Native Land. New York: Harper and Brothers.

Adamic, Louis (1946). America and Trieste, God and the Russians: A Letter to the Honorable James F. Byrnes, Secretary of State. New York: United Committee of South Slavic Americans.

Adamic, Louis (1951). "A Game of Chess in an Earthquake", unpublished chapter in the draft manuscript of The Eagle and the Roots. Ljubljana, Slovenia: Library of the Slovene Academy of Sciences and Arts.

Adamic, Louis (1952). The Eagle and the Roots. New York: Doubleday and Company.

Banac, Ivo (1992). "Historiography of the Countries of Eastern Europe: Yugoslavia." American Historical Review 97/4 (October), 1084-1104.

Basch, Linda, Glick Schiller, Nina, Szanton Bland, Cristina (1994). Nations Unbound: Transnational Projects, Postcolonial Predicaments and Deterritorialized Nation-States. Basel, United Kingdom: Gordon and Breach.

Borgwardt, Elizabeth (2005). A New Deal for the World: America's Vision for Human Rights. Cambridge, MA, Harvard University Press.

Djokic, Dejan (2003). "'After One Hundred Years': The Yugoslav Idea in Historical Perspective." Historically Speaking 5 (November), 18-21.

Enyeart, John P. (2019). Death to Fascism: Louis Adamic's Fight for Democracy. Urbana: University of Illinois Press.

Foner, Nancy (2000). From Ellis Island to JFK: New York's Two Great Waves of Immigration. New Haven, CT: Yale University Press.

Gabaccia, Donna, lacovetta, Franca (eds.) (2002). Women, Gender, and Transnational Lives: Italian Workers of the World. Toronto: University of Toronto Press.

Gaddis, John Lewis (1990). Russia, the Soviet Union, and the United Sates. New York: McGraw Hill.

Guglielmo, Jennifer (2010). Living the Revolution: Italian Women's Resistance and Radicalism in New York City, 1880-1945. Chapel Hill: University of North Carolina Press. Jacobson, Matthew Frey (1995). Special Sorrows: The Diasporic Imagination of Irish, Polish, and Jewish Immigrants in the United States. Berkeley: University of California Press.

Jurak, Mirko (1985). "'The New World' in Etbin Kristan's Plays." MELUS 12 (Winter), 53-61.

Klemenčič, Matjaž (1995). Slovenes of Cleveland: The Creation of a New Nation and a New World Community Slovenia and the Slovenes of Cleveland, Ohio. Novo mesto: Dolenjska Založba.

Klemenčič, Matjaž (1999). "Slovenia as Part of a United Europe in the Political Philosophy of Slovene Emigrants From Louis Adamic to Miha Krek." Intelektualci v Diaspori / Intellectuals in Diaspora (ed. Irena Gantar Godina). Proceedings of the 
Symposium 100th Birth Anniversary of Louis Adamic - Intellectuals in Diaspora, Portorož, Slovenia, 1-5 September, 1998.

LaFeber, Walter (2008). America, Russia, and the Cold War, 1945-2006. Boston: McGraw Hill.

Lees, Lorraine M. (1997). Keeping Tito Afloat: The United States, Yugoslavia, and the Cold War. University Park, Pennsylvania: The Pennsylvania State University Press.

Lees, Lorraine M. (2007). Yugoslav-Americans and National Security during World War II. Urbana, IL: University of Illinois Press.

Novak, C. Bogdan (1977). "American Policy Toward The Slovenes in Trieste, 19411974." Papers in Slovene Studies, 1-25.

Portes, Alejandro (1997). "Immigration Theory for a New Century: Some Problems and Opportunities." International Migration Review 31 (Winter), 799-825.

Ramet, Sabrina P. (2009). "The Meaning of Yugoslav History." Slovene Studies 31/2, 139-148.

Rogel, Carole (1977). The Slovenes and Yugoslavism, 1890-1914. New York: Columbia University Press.

Roosevelt, Franklin Delano (1941) "The 'Four Freedoms'", annual address to Congress, January 6, FDR Library website, http://docs.fdrlibrary.marist.edu:8000/od4frees. html (16. 7. 2010).

Seigel, Micol (2005). "Beyond Compare: Comparative Method after the Transnational Turn." Radical History Review (Winter), 62-90.

Weber, Devra Anne (2016). "Wobblies of the Partido Liberal Mexicano: Reenvisioning Internationalist and Transnational Movement through Mexican Lenses." Pacific Historical Review 85/2, 188-226.

Žitnik, Janja (1998). "Louis Adamic, a Slovene, an American, an Observer, a Fighter, a 'Poet'." Dve domovini / Two Homelands 9, 95-110.

\section{ARCHIVAL SOURCES}

Chicago History Museum, Ivan Molek Papers.

Narodna in univerzitetna Knjižnica Ljubljana, Louis Adamič Papers, M. S. 1858.

Princeton University, Firestone Library, Rare Books and Special Collections Department, Louis Adamic Papers.

\section{PERIODICALS AND NEWSPAPERS}

BUCSSA: The Bulletin of the United Committee of South-Slavic Americans (September 7, 1943; October 1945; April 1946; May 1946; and September 1946).

Democrat and Chronicle (Rochester, NY) (1946). June 4.

Flanntican Council on Other Religions. Oxford: Oxford University Press. 


\section{POVZETEK}

\section{TRST IN TRANSNACIONALNE IDENTITETE LOUISA ADAMIČA John Paul ENYEART}

Analiza Adamičevega aktivizma v obdobju od druge svetovne vojne do njegove smrti leta 1951 omogoča nov vpogled $v$ delovanje transnacionalizma na individualni ravni. V različnih načinih Adamičevega podpiranja jugoslovanskih zahtev do pristanišča Trst, ki je pozneje pripadlo Italiji, se kaže, kako je spreminjajoči se odnos med njegovo matično domovino in državo, v katero je emigriral, vplival na njegovo politično dejavnost. Med vojno je Adamič podpiral levičarsko vizijo jugoslavizma, po kateri naj bi južni Slovani vzpostavili narod etnično in politično enakopravnih pripadnikov. Adamič je vztrajal v prepričanju, da bo Tito ta cilj tudi uresničil, Trst pa bo postal glavno trgovsko središče nove Jugoslavije. Če bi Amerika zagotovila pomoč Jugoslaviji in jo naredila za svojo trgovsko partnerico, bi nova država po Adamičevem mnenju sčasoma prešla iz komunističnega $v$ demokratični režim. Ko je postalo jasno, da namerava vlada Združenih držav Trst dodeliti svoji nekdanji sovražnici, ne pa svoji novi prijateljici Jugoslaviji, je Adamič o Trstu začel govoriti kot o primeru ameriškega imperializma. 